\author{
Dorota Heidrich ${ }^{\star}$

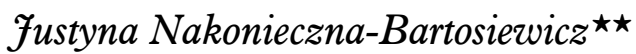

\title{
Young Activists as International Norm Entrepreneurs: A Case Study of Greta Thunberg's Campaigning on Climate Change in Europe and Beyond
}

\begin{abstract}
The role and significance of young activists in the process of international norm creation, diffusion, internalisation, and implementation have not received much attention in academic research. Yet, as a case study of Greta Thunberg campaigning on climate change has proven, children and teenagers can become significant norm entrepreneurs. Using the theoretical underpinnings of social constructivism, this article identifies and analyses Thunberg's actions to exhort pressure on states, members of governments and international organisations to further develop and implement norms that would help save the planet from the imminent climate crisis. Our research uses an exploratory and inductive approach in which qualitative research methods (a case study of Greta Thunberg) and discourse analysis are applied.
\end{abstract}

Keywords: International Norms, Climate Regime, Young Activists, Greta Thunberg, School Strike for Climate

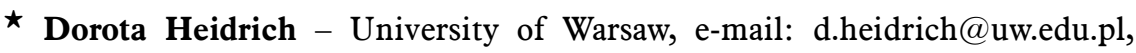
ORCID: 0000-0001-5135-4448.

$\star \star$ Justyna Nakonieczna-Bartosiewicz - University of Warsaw, e-mail: j.nakonieczna@uw.edu.pl,ORCID: 0000-0002-6783-1955. 


\section{Introduction}

This article analyses the role and significance of young activists ${ }^{1}$ in the process of international norms creation, diffusion, internalisation and implementation. The empirical evidence is drawn from the case study of the Swedish teenage climate activist Greta Thunberg, who has organised her own climate campaigns and inspired a broad movement of actors to act on the climate crisis, whose impact was particularly visible in Europe. The existing academic research on norm entrepreneurs (NE) is vast. Yet, it almost only recognises adult individuals as NE, omitting minors as agents of change. ${ }^{2}$ International Relations theory has not elaborated on the

${ }^{1}$ For the purpose of this research we have defined "young activists" as minors below the age of 18 who actively advocate for causes of national or international character. At the time of the conducted research and writing this paper, Greta Thunberg was a minor. She did turn 18 on $3^{\text {rd }}$ January 2021, however, to keep the research design coherent, at the stage of editing of this paper, we have decided not to include Greta's activities which took place after that date.

2 This omission is most probably related to the fact that children and teenagers (up to 18 years of age) are not seen as possessing the capacity to influence normative frameworks, as they have no legal capacity or their legal capacity is largely limited even in areas of interest to them. International relations scholarship is focused on children only as objects of reflection of the larger international community. Children need protection as individuals with special needs related to their legal status under domestic legislations. Therefore, norms have been created to protect them both in peacetime and in armed conflicts. Children's rights, of course, extend beyond protection from harm. Various non-legally binding documents endorse their rights and emphasise the importance of children's education and well-being for national development. Children are guaranteed by international legal norms and rights to education, medical healthcare, etc., and numerous governmental and non-governmental institutions act on behalf of the protection of children and providing assistance to them. The existing academic scholarship and non-academic sources on the role of children in IR and global issues, esp. the climate crisis (from various epistemological perspectives) include: S.R. Fisher, Life Trajectories of Youth Committing to Climate Activism, "Environmental Education Research", no. 22(2)/2015, pp. 229-247, DOI: https://doi.org/10.1080/13504622.2015.1007337; A. Corner et al., How do Young People Engage with Climate Change? The Role of Knowledge, Values, Message Framing, and Trusted Communicators, "WIREs Climate Change", no. 6/2015, pp. 523-534, DOI: https://doi.org/10.1002/wcc.353; A. Holmberg, A. Alvinius, Children's Protest in Relation to the Climate Emergency: A Qualitative Study on a New Form of Resistance Promoting Political and Social Change, "Childhood", no. 27(1)/2020, p. 7, DOI: https://doi. org/10.1177/0907568219879970; H. Thew et al., Youth participation and agency in the United Nations Framework Convention on Climate Change, "Int Environ Agreements", no. 18/2018, pp. 369-389, DOI: https://doi.org/10.1007/s10784-018-9392-2; H. Thew, L. Middlemiss, J. Paavola, "Youth is not a political position": Exploring justice claimsmaking in the UN Climate Change Negotiations, "Global Environmental Change", no. 61/2020, DOI: https://doi.org/10.1016/j.gloenvcha.2020.102036. For a journalist's 
role of children in the international community either. It must be noted, however, that observation of the activism of children and teenagers in such areas as the climate crisis shows that they have been playing an active role as norm entrepreneurs. In some cases, their voice and argumentation have resonated in decision making processes in both domestic and world politics. In their entrepreneurial actions, young activists become involved in issues that are of special interest to their well-being and future lives - examples, in addition to climate action, include the right to education. Moreover, as Joerg Forbrig observes, politically-involved youth may be characterised as possessing “...strong tendencies towards individualisation, and a profound disappointment with conventional politics and democracy, with traditional civic organisations and social movements, and with the logics of power and institutionalisation more broadly" which pushes them to act. ${ }^{3}$

The activism of young people against climate change did not begin with Greta Thunberg. During the 1992 Rio "Earth Summit", Severn Suzuki (at that time 12 years old), gave an emotional speech to the delegates on behalf of the Environmental Children's Organization (ECO). ${ }^{4}$ In it, she underlined: "I am fighting for my future. Losing my future is not like losing an election, or a few points on the stock market. I am here to speak for all generations to come. (...) I'm only a child and I don't have all the solutions but I want you to realise, neither do you. You don't know how to fix the holes in our ozone layer. You don't know how to bring the salmon back up in a dead stream. You don't know how to bring back an animal now extinct. And you can't bring back the forests that once grew where there is now a desert. If you don't know how to fix it, please stop breaking it". 5 After her speech, Severn Suzuki became known to the wider public and a frequent invitee to UN conferences.

compelling analysis see D.R. Fisher, Teen girls are leading the climate strikes and helping change the face of environmentalism, "The Washington Post", 24.09.2019, https:// www.washingtonpost.com/science/2019/09/24/teen-girls-are-leading-climate-strikeshelping-change-face-environmentalism/ (access 25.04.2021).

3 J. Forbrig, Introduction: democratic politics, legitimacy and youth participation, in: Revisiting Youth Political Participation: Challenges for Research and democratic practice in Europe, ed. J. Forbrig, Strasbourg 2005, p. 17.

${ }^{4}$ Severn Suzuki came to the "Earth Summit" as the representative of the youth of Canadian youth NGO with three Vancouver schoolmates - Michelle Quigg, Vanessa Suttie, and Morgan Geisler, she raised money to go to Rio.

5 The 5-minute speech is still known as "The girl who silenced the world for 5 minutes." Severn Cullis-Suzuki Speech at the Rio Summit 1992, https://youtu.be/oJJGu IZVfLM?list=PLfAjqE6VVDpUMolbS930mnv92yMuQAolw (access 25.04.2021). 
We perceive young activists as norm entrepreneurs. We claim that they try to influence and modify the international order which has the potential to impact the identities, preference, interests, and actions of actors who therefore might be more prone to continue to internalise the normative order.

Through a case study of Greta Thunberg's actions, our analysis aims to fill in the research gap on young activists as NE and their significance in the evolution and diffusion of international norms.

Our analysis is structured around two principal research questions:

1. What are the forms of activities characteristic of Greta Thunberg and can they be perceived as activities characteristic of norm entrepreneurs as a broader category?

2. Can it be proved that Greta Thunberg's (as a young activist and norm entrepreneur) actions have had an impact on state actors, international governmental institutions, and the international system?

We argue that the actions of young individuals such as Greta Thunberg can be perceived as actions characteristic of norm entrepreneurs, however, their impact on members of the international community, as well as for the international system (as a structure), can be identified only to a limited extent. The significance of young norm entrepreneurs is related to two basic characteristics of their actions: the extensive use of nontraditional organisational platforms (the Internet and social media) and the unequivocal and adamant presentation of the problems they advocate for which results from the very fact that they are children and teenagers whose voices are void of political correctness or limitations related to mature age. The entrepreneurial activity of young individuals appeared as a new element in the public discourse and has led to enhancing the process of the elaboration, diffusion, and internalisation of international norms.

The theoretical assumptions underpinning our analysis draw on the constructivist vision of the role and importance of individuals in the process of creating, promoting, and disseminating norms in the international community. ${ }^{6}$ We believe in the constructivist claim that the tissue of the international community is characterised by a certain normative structure that draws from the actions of different types of

${ }^{6}$ Constructivist scholarship on norms and beyond is extensive, beginning with such seminal works as that of Nicholas Onuf in 1989. Other scholars include Alexander Wendt and his monograph The Social Theory of International Politics published in 1999, DOI: https://doi.org/10.1017/CBO9780511612183, Martha Finnemore, Kathryn Sikkink, Margareth Keck, Ellen Lutz, Audie Klotz, Thomas Risse-Kapen, Stephen C. Ropp, Peter Katzenstein, F. Kratochwil, J. Checkel and many others. 
actors with various levels of agency. Constructivism uses non-material categories to explain processes taking place in international relations, without eschewing the consideration of the self-interest that can guide an individual. Furthermore, social constructivists see the international community as a structure in which actors operate with a specific agency in their actions. The interaction between the structure and the actor (agent) and the presence of certain norms or values in the structure leads to the construction of the identity and interests of the actors (agents). Actors' actions, in turn, have the power to influence changes in the structure. Young activists may be positioned among the agents that influence the structure.

Of particular importance for our work is Martha Finnemore's and Kathryn Sikkink's model of the life cycle of an international norm ${ }^{7}$ presented in the seminal article International Norm Dynamics and Political Change in 1998 in "International Organization". ${ }^{8}$ In this text, the authors distinguish the stages of norm development and diffusion and clearly delineate norm entrepreneurs' roles in these processes. ${ }^{9}$

Our research uses an exploratory and inductive approach, which results from the fact that there is a very limited scholarship on the phenomenon of youth and child activism as agents of change in international relations. We apply qualitative research methods; a case study (Greta Thunberg) and discourse analysis, which allowed us to draw conclusions from:

- 17 public addresses and speeches;

- 14 press publications and books;

- social media posts published by Thunberg on her Instagram and Twitter accounts, as well as on her Facebook profile from August $20^{\text {th }}$, 2018, to February $1^{\text {st }}, 2020 ;{ }^{10}$

7 M. Finnemore, K. Sikkink, International Norm Dynamics and Political Change, “International Organization", no. 52(4)/1998, DOI: https://doi.org/10.1162/ 002081 898550789.

8 Ibidem.

9 The life cycle of norms proposed by the authors is a three-stage process: Stage 1: norm emergence, followed by Stage 2: broad norm acceptance (the so-called "norm cascade") and Stage 3: norm internalisation. See Ibidem, p. 895. In their model, M. Finnemore and K. Sikking emphasise the significance of the role of norm entrepreneurs (individuals as agents of change among them) for Stage 1 (norm emergence) and Stage 2. Through institutionalised organisational platforms, norm entrepreneurs influence the members of the international community to approve of the promoted norm.

${ }^{10}$ Greta Thunberg does not personally maintain a Facebook account but has one on Twitter. Her official Facebook account has exactly the same posts as Twitter. Due to the easier access to Facebook, this is the main source of the posts initially analysed here. However, in further research, the Facebook posts were double-checked with Twitter posts. 
- 23 press articles, news feeds and other kinds of writings or video clips on Thunberg as well as that concerning the School Strike for Climate or Fridays for Future from: "The Guardian", "The Independent", "Time", "iD”, "GQ", "The Rolling Stone", "The New Yorker", "Die Weltwoche", "Open Democracy”, "news.com.au", Reuters, CNN, BBC News, and Dw News.

The case study and discourse analysis allowed us to single out and categorise Thunberg's concrete actions as an international activist and - as the next step - compare them to the model characteristic features of norm entrepreneurs in the "traditional" sense of the term. We also conducted a thorough analysis of addresses and statements given and issued by supporters and opponents of Thunberg's actions, which allowed us to observe whether the latter influence the normative structure that she targets by her actions.

In the first part of the paper, we conceptualise the notion of norm entrepreneurs and single out their specific characteristics. Next, we present Greta Thunberg as an individual and the timeline and features of her actions on behalf of the climate crisis. The following part analyses the impact of Thunberg's actions on governments, international organisations, and wider public opinion, which led to the mobilisation of people to combat climate change. In the last part of the analysis we provide the answer to the research questions, judge the validity of the hypothetical claim, as well as present a summary of the research results.

\section{Conceptualising Norm Entrepreneurs in IR}

Norms ${ }^{11}$ in international relations may be perceived as standards that provide solutions to coordination problems, reduce transaction costs,

11 We recognise the difference between norms, rules, principles and ideas. For this categorisation, see, e.g. S.D. Krasner, International Regimes, Ithaca, NY 1983 and Idem, Structural Causes and Regime Consequences: Regimes as Intervening Variables, "International Organization", no. 36(2)/1982, DOI: https://doi.org/10.1017/ S0020818300018920. In order to understand what makes norms distinctive among other kinds of rules is the prescriptive quality of "oughtness". See M. Finnemore, K. Sikkink, op.cit., p. 891. Ideas, in turn, do not need to be intersubjective, however, they might be shared by a community. What is more, ideas have no prescriptive character. Ideas however, may make a good start for norms. Once they are "framed", they may be pronounced as norms. The concept of framing is explained further in our study. See A. Björkdahl, op. cit, p. 43. The concept of ideas in international relations is elaborated in A.S. Yee, The Causal effect of Ideas on Policies, "International Organization", no. 50(1)1996, pp. 69-108, and in M. Finnemore, National Interests in International Society, Ithaca NY 1996, DOI: https://doi.org/10.7591/9781501707384. 
and "provide a language and grammar of international politics". ${ }^{12}$ They can also be defined as standards of appropriate behaviour for actors with a given identity ${ }^{13}$ or "as collective expectations about proper behaviour for a given identity", ${ }^{14}$ the breach of which may lead to sanctions, ${ }^{15}$ or simply as "shared understandings that make behavioural claims". ${ }^{16}$ Most of the definitions of norms clearly include two principal elements: a standard of behaviour or action and a feeling of obligation that is associated with the first element. For international relations scholars, norms are not necessarily always related to legal obligations. There might be norms that carry a certain moral or political obligation, and should a breach occur, a sanction may not be of a legal character either. Still, some kind of obligation needs to be in place for a norm to be called a norm. ${ }^{17} \mathrm{In}$ other words, all norms have a prescriptive character. Standard behaviour, as A. Bjorkhdal rightly observes, is an insufficient element of norms, a constant repetition of the same act does not necessarily create a norm of conduct. ${ }^{18}$ The first element of every norm (standard of behaviour, usus in international customary norm) is related to the feeling of appropriateness of behaviour that in turn is the result of a shared collective expectation of how actors should act. For norms will be norms only in a given social group with particular shared values and intersubjective understandings. In other words, interests and identities cannot be separated from norms that exist in a given society, also in the international one.

Norm entrepreneurs who act as "agents who influence the existing normative setting by amending existing norms or creating new ones" 19 can either be individuals (predominantly of interest to this study) or corporate (collective) actors. The former include individuals who act or used to act

12 A.P. Cortell, J.W. Davies, Understanding the Domestic Impact of International Norms: A Research Agenda, "International Studies Review", no. 2(1)/2000, pp. 65-66, DOI: https://doi.org/10.1111/1521-9488.00184.

${ }_{13}$ M. Finnemore, K. Sikkink, op.cit., p. 891.

14 Ibidem.

15 R. Axelrode, An Evolutionary Approach to Norms, "American Political Science Review", vol. 80, no. 4/1986, DOI: https://doi.org/10.1017/S0003055400185016.

16 J.T. Checkel, Norms, Institutions and National Identity in Contemporary Europe, "International Studies Quarterly", no. 43(1)/1999, p. 88, DOI: https://doi. org/10.1111/0020-8833.00112.

17 For the normal to become normative, a feeling of obligation needs to be added, and the behaviour must be driven by norms. See A. Florini, The Evolution of International Norms, "International Studies Quarterly", no. 40(3)/1996, p. 364, DOI: https:// doi.org/10.2307/2600716.

18 A. Björkdahl, From Idea to Norm-Promoting Conflict Prevention, "Lund Political Studies. Department of Political Science, Lund University", no. 125/2002, p. 40.

19 Ibidem, p. 46. 
as official representatives of states, international organisations, are public figures known for other activities (actors, singers and celebrities), or activists who build their influence only around the subject matter they undertake to promote. Corporate actors in turn include states, through international governmental (IGOs) and non-governmental organisations (NGOs), transnational activist networks (TANs), as well as other state and intergovernmental level institutions. Norm entrepreneurs have a role to play in international norm promotion and diffusion but also in socialising ${ }^{20}$ state actors to emerging norms and principles and in the processes of their domestic internalisation. Their actions do not always lead to successful internalization of the proposed normative order or at least it will not always happen imminently. Oftentimes norm entrepreneurs strive for years or even decades to make sure that their aims are reached, as for example the life and work of Raphael Lemkin suggests.

The term "norm entrepreneurs" is related to the concept of "transnational moral entrepreneurs" defined by E.A. Nadelmann as groups that mobilise popular opinion and political support both within their host country and abroad. ${ }^{21}$ Nadelmann also saw them as stimulating and assisting in the creation of like-minded organisations in other countries and playing a significant role in elevating their objective beyond its identification with

20 Socialisation may be defined as the process by which states internalise norms arising elsewhere in the international system. See K. Anderson, Making Sense of State Socialization, "Review of International Studies", no. 27/2001, p. 417, DOI: https://doi. org/10.1017/S0260210501004156. Socialisation may be influenced and conditioned by external factors, however, one must not exclude domestic ones; both may coexist, or it may happen by contagion. Another possible factor inducing socialisation is the actions of the international community. Its members use the carrot and stick method to encourage adoption of norm-based manners of behaviour. Kenneth Waltz discussed the socialisation of agents in a structure through following leaders and heroes. Waltz said that behaviour aligned with the norms is raised and that is why it is enhanced. There will always be agents of a structure who prefer to deviate from the intersubjectively existing prescription but their actions would be disregarded or ridiculed and often these members of a group (social group, the international community) would be forced to leave and become outcasts. Because most agents do not wish to become outcasts, they will be socialised to the existing norms, even if they see it as repressive. In that sense, structures influence and constitute agents. In the international community, socialisation to norms may result from economic, financial, political or simply symbolic pressures. See J. Subotić, Hijacked Fustice. Dealing with the Past in the Balkans, Ithaca-London 2009, pp. 30-33. M. Finnemore and K. Sikkink point to three predominant motivations for socialisation: legitimation, conformity and esteem. See M. Finnemore, K. Sikkink, op.cit.

${ }^{21}$ E.A. Nadelmann, Global Prohibition Regimes: The Evolution of Norms in International Society, “International Organization”, no. 44(4)/1990, p. 482, DOI: https://doi. org/10.1017/S0020818300035384. 
the national interests of their government. ${ }^{22}$ Other terms that relate to the concept of norm entrepreneurs used in scholarly literature include "normmakers", ${ }^{23}$ "policy entrepreneurs" ${ }^{24}$ or "meaning managers"/"meaning architects" 25 who all bring about and promote certain ideas ${ }^{26}$ and transform them into concrete proposals, be they of a political or legal nature.

The role that norm entrepreneurs play is most frequently related to persuasion (changing other players' utility functions to reflect some new normative commitment $)^{27}$ by which agent action becomes social structure, ideas become norms, and the subjective becomes intersubjective. ${ }^{28}$ According to E.A. Nadelmann, the propositions of norm entrepreneurs are to persuade foreign audiences that a particular norm reflects a widely shared or even universal moral sense, rather than the peculiar moral code of one society. ${ }^{29}$

${ }^{22}$ Ibidem.

${ }^{23}$ J.T. Checkel, op.cit., pp. 84-85.

24 "Policy entrepreneurs are rather regarded to be corporate or individual actors that set political agendas or, as J.K. Jacobsen has put it "are usually interested actors who benefit when their ideas are adopted". See J.K. Jacobsen, Much Ado About Ideas: The Cognitive Factor in Economic Policy, "World Politics", no. 47(2)/1995, DOI: https:// doi.org/10.1017/S0043887100016117. See also M.A. Pollack who perceives "policy entrepreneurs", following A. Moravcsik, as actors holding the power to set informal agendas "of an organisation, not through its formal powers but through its ability to define issues and present proposals that can rally consensus among the final decision maker". According to A. Moravcsik, "policy entrepreneurs" “exercise 'leadership' rather than formal power". See M.A. Pollack, Delegation, Agency, and Agenda Setting in the European Community, "International Organization", no. 51(1)/1997, p. 121, DOI: https://doi.org/10.1162/002081897550311 and A. Moravcsik, A New Statecraft? Supranational Entrepreneurs and International Cooperation, "International Organization", no. 53(2)/1999, p. 268, DOI: https://doi.org/10.1162/002081899550887. See also K. Stoeckl, The Russian Orthodox Church as moral norm entrepreneur, "Religion, State \& Society", no. 44(2)/2016, pp. 132-151, DOI: https://doi.org/10.1080/09637494.2016.1194010; S. Rushton, The UN Secretary-General and Norm Entrepreneurship: Boutros Boutros-Ghali and Democracy Promotion, "Global Governance", no. 14(1)/2008, pp. 95-110, DOI: https://doi.org/10.1163/19426720-01401007; D.R. Fisher, How Do Organisations Matter? Mobilisation and Support for Participants at Five Globalization Protests, "Social Problems", no. 52(1)/2005, pp. 102-121, DOI: https://doi.org/10.1525/sp.2005.52.1.102.

25 According to L. Lessig, "a meaning manager" or a "meaning architect", is an actor "who has identified a social meaning that is to be transformed, and must find the techniques to achieve this transformation". L. Lessig, The Regulation of Social Meaning, "University of Chicago Law Review", no. 62(3)/1995, p. 1008, DOI: https:// doi.org/10.2307/1600054.

26 A. Björkdahl, op.cit., p. 45.

${ }_{27}$ M. Finnemore, K. Sikkink, op.cit., p. 914.

${ }^{28}$ Ibidem.

${ }^{29}$ E.A. Nadelmann, op.cit., p. 482. 
In the history of the evolution processes of international norms there are a number of individuals who can be called norm entrepreneurs. M. Finnemore and K. Sikkink mention Henry Dunant who stood behind the creation of the Committee of the Five (predecessor of the International Committee of the Red Cross) and the Geneva Convention of 1864 or Elizabeth Candy Stanton, Susan B. Anthony, Millicent Garrett Fawcett and Emmeline Pankhurst, leaders of the women's suffrage campaign. ${ }^{30}$ One can also include here the actions of celebrities who get involved in already existing movements or actions for a certain cause, for example Lady Diana Spencer (who gave her strong support to the campaign on the prohibition of anti-personnel landmines); George Clooney (who has campaigned for recognising the crimes committed in Darfur as genocide); Leonardo di Caprio (involved in the fight against inaction on climate change) or Angelina Jolie (the good-will ambassador for United Nations High Commissioner for Refugees acting on the promotion of rights of refugees across the world). Other examples may include such corporate actors like the Coalition for the International Criminal Court or the International Campaign to Ban Landmines. D. Madokoro also claims that international commissions can be seen as norm entrepreneurs and discusses the example of the International Commission on Intervention and State Sovereignty. ${ }^{31}$ In many of these examples norm entrepreneurs are important at the stage of creation of normative expression of oughtness or state socialization to norms (voting rights for women, protection of sick and wounded in the battlefield, naming human rights violations genocide which pertains to possible legal consequences, prohibition of the use of land mines, etc.). We however argue that one should see the role of norm entrepreneurs much more broadly: it can also be significant once the normative order has already been formed, the actors have been socialised to a particular norm but its internalisation seems to be selective or apparent. This is how we see the actions of states in relation to the fight against the climate crisis. The existence of the normative and institutional order defined as a "climate regime" and the characteristics of its assumptions and contents do not raise any doubts. However, the actions of states in the implementation of their commitments clearly deviate from or even contradict the assumed climate goals. Thus, the activities of the norm entrepreneurs acquire a new meaning and importance, appearing as if outside the model of the life cycle of international norms proposed by

${ }^{30}$ M. Finnemore, K. Sikkink, op.cit., p. 897 and following.

31 D. Madokoro, International commissions as norm entrepreneurs: Creating the normative idea of the responsibility to protect, "Review of International Studies", no. 45(1)/2019, DOI: https://doi.org/10.1017/S0260210518000219. 
M. Finnemore and K. Sikkink who limit their actions to the presented stages of the cycle. Regardless of the stage of norm creation and diffusion, the actions of norm entrepreneurs will be effective if they themselves are characterised by certain traits but also when favourable conditions exist for their actions. Only then will members of the international community (most importantly states) be ready to endorse the emerging norm. In turn, this will lead to the tipping point in the life cycle of international norms which would mean that the number of the norm supporters may guarantee the cascading normative change. In our view, norm entrepreneurs can be characterised by the following traits: 1 . the force of dedication (strong commitment to the promoted norm and altruistic in their actions); 2. the force of commitment (ability to influence the international setting and members of the international community); 3 . the force of appropriateness (ability to speak to universal or at least regional contexts and values); 4. the capacity of framing (ability to properly frame the promoted issue); 5. the force of mobilisation (ability to create or engage organisational platforms (IGOs, NGOs, TANs) which support and amplify the actions of norm entrepreneurs). ${ }^{32}$ The forthcoming part of the analysis aims to characterize Greta Thunberg and her actions on the climate crisis through the lens of these traits.

\section{Characteristics of Greta Thunberg and Her Actions to Combat the Climate Crisis}

Greta Thunberg became a publicly known figure in the context of her actions on behalf of climate change on August $20^{\text {th }}, 2018$, when at the age of 15, she started her protest in front of the Swedish Parliament. The action became known under the name "School strike for climate" (Skolstrejkförklimatet). Later the protest that became the inspiration for global actions, was reduced to Fridays only (this is where the currently used name of the school strikes comes from - "Fridays for Future"). ${ }^{33}$ Greta used different organisational platforms to explain her actions and

32 The presented set of attributes is a modified compilation of the originally adopted by Finnemore and Sikkink. Ibidem M. Keck, K. Sikkink, Activists beyond Borders: Advocacy Networks in International Politics, Ithaca-NY 1999.

${ }_{33}$ This weekly schoolwork strike was inspired by the survivors of February 2018's school shooting in Parkland, Florida USA. The school climate strikes were organized in the previous years. For instance, in 2015 during the UN Climate Change Conference in Paris, students from over 100 countries (around 50000) organised the climate strike and skipped school demanding climate actions: see Climate Strike 2015: Students Skip School demanding Climate Actions. Climate Strike, 1.03.2016, https://www. youtube.com/watch? $=0 \mathrm{GjdVgGfcb8}$ (access 25.04.2021). 
to implore politicians and decision makers to support her demands and take steps towards halting carbon emissions.

The organisational platforms used by Thunberg can be divided into 3 categories: social media, followed by platforms created with a purpose to support Thunberg's actions and existing climate movements and organisations.

The intensive use of social media by Greta in her actions is an expression of a broader trend that has accompanied activism for many years. ${ }^{34}$ Thunberg has therefore used the available tools to support her environmental claims. The most important organisational frameworks that support her activities are formed on Twitter, Instagram and Facebook. From there she directly calls the young people to take part in climate strikes, publishes her accounts of meetings, events, as well as her speeches. It was through Twitter that she addressed President Donald Trump directly, warning him that if he refused to understand that the climate crisis was the biggest crisis humanity had ever faced, and would not act, he was "going to be seen as one of the worst villains in human history". ${ }^{35}$

The organisation of demonstrations and school strikes were also supported and co-coordinated by existing ecological organisations, such as: Sunrise Movement, 350.org, OneMillionOfUs, Earth Uprising, Future Coalition, Earth Guardians, Zero Hour, and Extinction Rebellion.

The importance of supporting Greta Thunberg's activities, especially before Fridays For Future became a functioning international social movement, has been recognised by the UN Network International Youth Climate Movement. At the UN Climate summits and conferences, Greta would speak as a representative of the youth network's voice and on its behalf. For example, she represented Climate Justice Now when she addressed the participants of UN COP24 in Katowice. ${ }^{36}$

In November 2018, she appeared in the Swedish edition of TEDxStockholm, explaining the motives for the school climate strike. ${ }^{37}$ As mentioned above, her breakthrough speech at UN COP24 in Katowice had a huge effect. From then, the invitations to international forums started pouring in from all over the world. During the following 13 months after

${ }^{34}$ D. Murthy, Introduction to Social Media, Activism, and Organizations, "Social Media + Society", no. 4(1)/2018, DOI: https://doi.org/10.1177/2056305117750716.

35 Brut.com, 16-year-old Greta Thunberg In A Brut Interview, “Brut.com”, 19.02.2020, https:/www.facebook.com/watch/?v=2612830962066751 (access 25.04.2021).

${ }^{36}$ G. Thunberg, Address at the COP24 plenary session, 12.12.2018, https://www.youtube.com/watch?v $=\mathrm{Z1}$ znxp8b65E (access 25.04.2021).

${ }^{37} \mathrm{G}$. Thunberg, School strike for climate - save the world by changing the rules, TEDxStockholm, November 2018, https://www.ted.com/talks/greta_thunberg_the_disarming_case_to_act_right_now_on_climate_change (access 25.04.2021). 
UN COP24, she took part in international meetings devoted to climate change and climate crisis. She gave speeches at:

- The World Economic Forum in Davos, Davos, Switzerland, January 22 $2^{\text {nd }}, 2019$;

- European Economic and Social Committee during the EESC event "Civil Society for rEUnaissance”, Brussels, Belgium, February 21 $1^{\text {st }}, 2019$;

- EU Parliament session, Strasbourg, France, April 16 $6^{\text {th }}, 2019$;

- Houses of Parliament session, London, UK, April 23 ${ }^{\text {rd }}, 2019$;

- Austrian World Summit (in the presence of Secretary-General Guterres, President Van der Bellen, Arnold Schwarzenegger and heads of states), Vienna, Austria, May 28 ${ }^{\text {th }}$, 2019;

- Brilliant Minds conference, Stockholm, Sweden, June 13 ${ }^{\text {th }}, 2019$;

- National Assembly, Paris, France, July 23 ${ }^{\text {rd }}, 2019$;

- US Congress (Senate) session, Washington, US, September 19 ${ }^{\text {th }}, 2019$;

- UN Climate Action Summit, New York, US, September 23 ${ }^{\text {rd }}, 2019$;

- UN Climate Change conference, Madrid, Spain, December 11 $1^{\text {th }}, 2019$;

- World Economic Forum in Davos - Forging a Sustainable Path towards a Common Future (organised alongside other teenage activists), Davos, Switzerland, January $21^{\text {st }}, 2021$.

Since Greta Thunberg initiated her action, she has met individually with politicians, decision-makers, scientists and celebrities to convince them of her cause. These have Jeremy Corbyn, Pope Francis, Barack Obama, Antonio Guterres, Alexander van der Bellen, Alexandria OcasioCortes, as well as Chancellor Angela Merkel, who hosted Greta Thunberg and other leading Fridays for Future activists in Berlin for talks on the EU's climate goals. ${ }^{38}$ Other meetings worth mentioning were organised with Arnold Schwarzenegger, Naomi Klein, Jane Goodall, David Attenborough, and activists Severn Suzuki and Malala Yousafzai.

Greta Thunberg's speeches are very emotional, using a naming and shaming communication technique. Speaking before her 18th birthday Greta strongly emphasised the fact that she was a juvenile who spoke to adults on behalf of youngsters and children, setting the axis of

${ }^{38}$ Various official posts by Greta Thunberg on Instagram; G. Thunberg, L. Neubauer, A. Valenzuela, Why We Strike Again, Article-Call, "Project Syndicate", 29.11.2019, https:/www.project-syndicate.org/commentary/climate-strikes-un-conference-madrid-by-greta-thunberg-et-al-2019-11 ?fbclid=IwAR3XjvypiCJXAkAhTTpWEBx 2aYEBnn4Y8_83NGqDzJhpgeOXCFC3Jtb2w3o (access 25.04.2021); Merkel meets Thunberg and other climate activists, "DW News", 20.08.2020, https://www.dw.com/en/ merkel-meets-thunberg-and-other-climate-activists/av-54641827 (access 25.04.2021). 
argumentation on a dichotomous relationship: we children, instead of enjoying being children, have to take matters into our own hands because adults have failed and have let us down. Examples of that manner of communication may be cited:

"My message is that we'll be watching you. This is all wrong. I shouldn't be up here. I should be back in school on the other side of the ocean. Yet you all come to us young people for hope. How dare you!" ${ }^{39}$

"We children are doing this to wake the adults up. We children are doing this for you to put your differences aside and start acting as you would in a crisis. We children are doing this because we want our hopes and dreams back". ${ }^{40}$

"You say you love your children above all else and yet you're stealing their future in front of their very eyes. Until you start focusing on what needs to be done rather than what is politically possible there is no hope". ${ }^{41}$

Mass climate strikes undertaken by children are presented by Greta in her speeches as mature and responsible behavior in a crisis. In a situation where our existence is threatened, it is the children who take action and demand that steps be taken to halt climate change, thus facing the challenge, unlike adults. She shocks adults (insulting them in this way), calling them children, while she talks of children as mature human beings; Greta's "adults-children" do take decisions, do not know the intricacies of the world and are depicted as passive individuals:

"You are not mature enough to tell it like it is. Even that burden you leave to us children". ${ }^{4}$

"You need to listen to us, we who cannot vote. You need to vote for us, for your children and grandchildren. What we are doing now can soon no longer be undone". ${ }^{43}$

39 G. Thunberg, Speech At The UN Climate Action Summit, 23.09.2019, https:// www.youtube.com/watch? $\mathrm{v}=\mathrm{u} 9 \mathrm{KxE} 4 \mathrm{Kv} 9 \mathrm{~A} 8$ (access 25.04.2021).

40 G. Thunberg, 'You did not act in time': Greta Thunberg's full speech to MPs, "The Guardian”, 23.04.2019, https://amp.theguardian.com/environment/2019/apr/23/ greta-thunberg-full-speech-to-mps-you-did-not-act-in-time? twitter_impression =true\&fbclid =IwAR1y7qFbZzwtyFEuiMCHf4qLdjKlh0WSW 81 RlffuN 5zLHxqezJq vluiVp3w (access 25.04.2021).

${ }^{41}$ G. Thunberg, Address at the COP24..., op.cit.

${ }^{42}$ Ibidem.

43 G. Thunberg, Speech at the EU Parliament..., 16.04.2019, https://youtu.be/ cJAcuQEVxTY (access 25.04.2021). 
"Striking is not a choice we relish; we do it because we see no other options. We have watched a string of United Nations climate conferences unfold. Countless negotiations have produced much-hyped but ultimately empty commitments from the world's governments the same governments that allow fossil-fuel companies to drill for evermore oil and gas, and burn away our futures for their profit". ${ }^{44}$

Greta refers in a negative way to slogans used in documents on the future of the world and on the related concerns for the future of next generations:

"So we have not come here to beg the world leaders to care for our future. They have ignored us in the past and they will ignore us again. (...) And why should I be studying for a future that soon may be no more, when no one is doing anything to save that future? And what is the point of learning facts when the most important facts clearly mean nothing to our society?". ${ }^{5}$

Another axis of emotional argumentation is to criticise adults, especially political and economic leaders, for excessive consumerism and short-sightedness in actions that halt or slow down actions aimed at stopping the climate disaster:

"Entrepreneurs, celebrities, politicians, business leaders. People who have a lot of power. People who consume enormous amounts of stuff. Who often fly around the world, sometimes in private jets. Your individual carbon footprints are in some cases the equivalent of whole villages. But the worst part I think is that you are normalising this extreme lifestyle. Because people look up to you. You are the role models, you are setting the standards. People aspire to be like you". ${ }^{46}$

Greta frames climate challenges as a "crisis" and applies sharp words and terms such as "panic", "the last minute/moment before the disaster happens", presenting the reality in sharp black or white distinctive colours. She also puts together the words, "child"/"children" and "mature"/"maturity". Here again, children are presented as mature, contrary to adults:

${ }^{44}$ G. Thunberg, L. Neubauer, A. Valenzuela, op.cit.

45 G. Thunberg, Speech to UN secretary-general António Guterres at UN Climate Change COP24 Conference, 3.12.2018, https://youtu.be/Hq489387cg4 (access 25.04.2021).

${ }^{46}$ G. Thunberg, Speech at the Brilliant Minds conference in Stockholm, 13.06.2019, https://www.facebook.com/watch/?v=1454977894643083 (access 25.04.2021). 
"Other adults keep saying: "We owe it to the young people to give them hope.” But we don't want your hope. We don't want you to be hopeful. We want you to panic and we want you to take action. We want you to join us". ${ }^{47}$

"Our house is on fire, I am here to say our house is on fire. According to the IPCC we are less than 12 years away from not being able to undo our mistakes". ${ }^{4}$

Her statements are constructed as direct and unambiguous, in which she stigmatises complicating the reality rather than perceiving it as a clear crisis that simply must be resolved:

"Don't you think that a 16-year old can speak for herself? There's also some people who say that I oversimplify things. For example when I say that "the climate crisis is a black and white issue», "we need to stop the emissions of greenhouse gases», and «I want you to panic». But that I only say because it's true. Yes, the climate crisis is the most complex issue that we have ever faced and it's going to take everything from our part to «stop it». But the solution is black and white; we need to stop the emissions of greenhouse gases". ${ }^{4}$

"I don't understand that, because if the emissions have to stop, then we must stop the emissions. To me that is black or white. There are no grey areas when it comes to survival. Either we go on as a civilisation or we don't". ${ }^{50}$

She also reminds adults of their ignorance and pretence that nothing terrible is happening, and of underestimating the climate movement:

"And not once, not one single time have I heard any politician, journalists or business leader even mention these numbers. It is almost like you don't even know they exist, as if you haven't even read the latest IPCC reports on which the future of our civilisation is depending". ${ }^{51}$

${ }^{47}$ G. Thunberg, A. Taylor and others, Think we should be at school? Today's climate strike is the biggest lesson of all, "The Guardian", 15.03.2019, https://www.theguardian.com/commentisfree/2019/mar/15/school-climate-strike-greta-thunberg (access 25.04.2021).

${ }^{48}$ G. Thunberg, Speech "Our House is on Fire", World Economic Forum (WEF) in Davos, January 2019, https://youtu.be/M7dVF9xylaw (access 25.04.2021).

${ }^{49} \mathrm{G}$. Thunberg, Post on Facebook, 11.02.2019, https://www.facebook.com/gretathunbergsweden/photos/a.733630957004727/773673599667129/?type $=3 \&$ theater $($ access 25.04.2021).

${ }^{50}$ G. Thunberg, School strike for climate..., op.cit.

${ }^{51}$ G. Thunberg, Speech at the National Assembly in Paris, 23.07.2019, https://youtu. be/ESDpzwWrmGg (access 25.04.2021). 
"We have come here to let them know that change is coming whether they like it or not. The people will rise to the challenge. And since our leaders are behaving like children, we will have to take the responsibility they should have taken long ago". 52

We may also single out persuasive communication, based on short "must do" messages in Greta's speeches:

"You must unite behind science. You must take action. You must do the impossible. Because giving up can never ever be an option".53

Many excerpts from her statements have become slogans written on banners at demonstrations or repeated as viral statements about the climate crisis: Our house is on fire, No one is too small to make a difference ${ }^{54}$ or the opening words of her address to the UN: How dare you! You have stolen my dreams and my childhood with your empty words.

The rational argumentation used in Thunberg's addresses refers to concrete solutions that could save humanity from a climate catastrophe. Thunberg sees an opportunity in implementing the recommendations of the Paris Agreement, as long as mankind, according to the best state of the art available (especially reports issued by the IPCC), ${ }^{55}$ has time for this. She points out that the already invented solutions have a chance to protect us from disaster, but they are not being implemented at all or are too slow, despite numerous declarations and promises. Thunberg rejects the argument that climate change is a complicated matter, arguing that the crisis situation in which we find ourselves, compels us to leave the old patterns behind.

${ }_{52}$ G. Thunberg, Speech to UN secretary general..., op.cit.

${ }_{53}$ G. Thunberg, Speech to the US Congress, Washington DC, 18.09.2019, "Independent", Transcript, 20.09.2019, https:/www.independent.co.uk/voices/greta-thunbergcongress-speech-climate-change-crisis-dream-a9112151.html (access 25.04.2021).

54 G. Thunberg, Post on Facebook, 17.03.2019, https://www.facebook. com/732846497083173/posts/793441724356983 (access 25.04.2021).

55 The 2015 Paris Agreement (signed by 190 countries, entered into force on November 4, 2016) builds upon the United Nations Framework Convention on Climate Change from 1994. The agreement is considered to be the first ever universal, legally binding global climate change agreement, in which governments agreed to strengthen the global response to the threat of climate change by keeping a global temperature rise this century well below 2 degrees Celsius above pre-industrial levels and to pursue efforts to limit the temperature increase even further to 1.5 degrees Celsius. The agreement aims to increase the ability of countries to deal with the impacts of climate change, and at making finance flows consistent with a low GHG (GreenHouseGas) emissions and climate-resilient development. See Paris Agreement to the United Nations Framework Convention on Climate Change, 12.12.2015, https:// unfccc.int/files/meetings/paris_nov_2015/application/pdf/paris_agreement_english_. pdf (access 25.04.2021). 
"When I tell politicians to act now, the most common answer is that they can't do anything drastic, because that would be too unpopular among the voters. And they are right of course, since most people are not even aware of why those changes are required. That is why I keep telling you to unite behind the science, make the best available science the heart of politics and democracy". ${ }^{56}$

Thunberg makes conscious and meticulous reference to data from climate reports and scientific knowledge, quoting scientists:

"A lot of people, a lot of politicians, business leaders, journalists, say they don't agree with what we are saying. They say we children are exaggerating, that we are alarmists. To answer this, I would like to refer to page 108, chapter 2 in the latest IPCC report. There you will find all our "opinions" summarised, (...)". ${ }^{57}$

“There is one other argument that I can't do anything about. And that is the fact that I'm «just a child and we shouldn't be listening to children.» But that is easily fixed - just start to listen to the rock solid science instead. (...) I am just a messenger (...)". ${ }^{58}$

Thunberg's arguments have been strengthened and the climate crisis issue was even more accurately framed in September 2019 when she and 15 other children filed a complaint with the United Nations alleging that five of the world's major economies (Argentina, Brazil, France, Germany and Turkey) have violated their human rights by not taking adequate action to stop the unfolding climate crisis. ${ }^{59}$

${ }^{56}$ G. Thunberg, Speech at the EU Parliament..., op.cit.

57 G. Thunberg, Speech at the National Assembly in Paris..., op.cit.

${ }_{58}$ G. Thunberg, Post on Facebook, 11.02.2019, op.cit.

59 D. Kann, Greta Thunberg and 15 other children filed a complaint against five countries over the climate crisis, "CNN", 23.09.2019, https:/edition.cnn.com/2019/09/23/ world/united-nations-greta-thunberg-children-climate-change-human-rights-complaint/index.html. (access 25.04.2021). Brazil, France and Germany have rejected the complaint and claimed that it should not be admissible before the Committee. The three have claimed that the petitioners were not within their jurisdiction as required by Article 2(1) of the Convention of the Rights of the Child and Article 5 of the Optional Protocol (that allows for individual complaints before the Committee) "and in particular, that they do not fall within the scope of the respondent States' extraterritorial jurisdiction". For details of the case and the argumentation of the governments of Brazil, France and Germany see K. Bakker, Baptism of fire? The first climate case before the UN Committee on the Rights of the Child, "QIL, Zoom-in", no. 77/2021, pp. 5-25. The decision on its admissibility is pending. Greta Thunberg and children's group hit back at attempt to throw out climate case, "The Guardian", 5.05.2020, 
Thunberg also stresses in her statements that not only is she independent of adult influence, but that her actions are not for profit, but for ideas: "I have not met one single climate activist who is fighting for the climate for money. That idea is completely absurd". 60

Greta decided to donate to non-governmental organisations all the financial awards that she received in praise for her actions and the profits from the sale of her publications (the book No One Is Too Small to Make A Difference, ${ }^{61}$ authored by Greta and her family) are to be used for charity. On January $29^{\text {th }}$, 2020 Greta Thunberg applied to trademark her name to prevent misuse. ${ }^{62}$ Her parents also instituted a foundation named after her and her sister to better protect their rights. ${ }^{63}$ The name of the global movement "Fridays For Future" is also legally protected, as Thunberg said, so "that it can - and must - not be used for individual or commercial purposes". ${ }^{64}$

https://www.theguardian.com/environment/2020/may/05/greta-thunberg-and-childrens-group-hit-back-at-attempt-to-throw-out-climate-case (access 25.04.2021). For the status of individual complaints before the Committee see OHCHR, The case is still pending before the committee. Table of Pending Cases before the Committee on the Rights of the Child, https://www.ohchr.org/Documents/HRBodies/CRC/TablePendingCases. pdf. (access 25.04.2021). It is also worth mentioning that on 30th November 2020 the European Court of Human Rights in Strasbourg called the governments of 33 industrialized countries to promptly respond to a climate lawsuit lodged by six youth campaigners in September 2020, giving it priority status because of the "importance and urgency of the issues raised." It was the response to the complaint filed by six Progugese youth: four children (aged 8, 12,15, and 17) and two young adults (of age 20 and 21), supported by Global Legal Action Network (GLAN) who accused 33 industrial countries that heat waves resulting from these countries were affecting the applicants' living conditions and health of the applicants. GLAN, Press Release: Unprecedented climate case clears major hurdle as European court recognises "importance and urgency", 30.11.2020, https://youth4climatejustice.org/wp-content/uploads/2020/11/ GLAN-CLIMATE-CASE-PRESS-RELEASE-embargoed-until-00.01-30.11.20-1. pdf (access 25.04.2021); European Court of Human Rights, Communicated Case: Duarte Agostinho et Autres c. Portugal et 32 Autres États, 39371/20, http://hudoc.echr.coe. int/eng? $\mathrm{i}=001-206535$ (access 25.04.2021).

60 G. Thunberg, Post on Facebook, 11.02.2019, op.cit.

${ }_{61}$ G. Thunberg, No One Is Too Small to Make a Difference, Penguin Books Ltd. 2019. It is worth noting that her book is similar in nature to what Severn Suzuki did over 30 years ago (see S. Suzuki, Tell the World, Doubleday Canada, 1993).

62 Skolstrejk for klimatet registration details on: https://www.tmdn.org/tmview/ get-detail?st13=EM500000018171383\&lang=en\# (access 25.04.2021).

${ }_{63}$ G. Thunberg, Post on Facebook, 30.01.2020, https://www.facebook.com/gretathunbergsweden/photos/a.733630957004727/1047447982289688/?type =3\&theater (access 25.04.2021); Stiftelsen The Greta Thunberg and Beata Ernman Foundation was registered in May 2020.

${ }^{64}$ Ibidem. 


\section{The Influence of Greta Thunberg's Actions on Governments, International Organisations and Public Opinion}

Greta Thunberg directs protests at politicians, members of governments, business people, officers of in ternational organisations and public opinion worldwide. Her actions mobilise people to act to combat climate change.

The announcement of the beginning of her campaign quickly became viral, attracting the attention of huge numbers of social media users ${ }^{65}$ and traditional media channels. ${ }^{66}$

We have identified a broad range of audience feedback of both a positive and negative character. The allies that have lent credence to the climate protests of children and adolescents and strengthened the impact of Greta Thunberg's message are first and foremost scientists and researchers who in open letters published in both the press (e.g., an open letter of 224 lecturers, expressing their support for Greta Thunberg and the climate strike ${ }^{67}$ published in "The Guardian" on February $13^{\text {th }}, 2019$ ) and in scholarly journals (as in "Science" in April 2019 a letter authored by 21 scientists who justified the concerns of the young protesters)..$^{68}$

Greta herself in a sense became a celebrity which was related mainly to the interest of traditional media in her actions and her as a person. She gave interviews and appeared on the covers of several newspapers and magazines: "Time" (twice: on May 27 ${ }^{\text {th }}, 2019$ and after receiving the title of the person of the year on December 23 ${ }^{\text {rd }}$,2019), "The Guardian Weekend" (June 29th 2019), "i_D” magazine (no. 356, Summer 2019), “GQ” magazine (October 2019), "The Rolling Stone" magazine (April 2020). She has been nominated to or honoured with 9 national, regional and global awards, including a nomination for the Nobel Peace Prize (see Table 1).

${ }^{65}$ G. Thunberg, Post on Facebook, 11.02.2019, op.cit.

66 See for example, media associated in the Climate Media Coalition: http://climatemediacoalition.org/ (access 25.04.2021).

67 Open Letter of scholars, School climate strike children's brave stand has our support, "The Guardian", 13.02.2019, https://www.theguardian.com/environment/2019/ feb/13/school-climate-strike-childrens-brave-stand-has-our-support?fbclid=IwAR3 n8aFnEYECFk7w4IeV7UEwVd_oehNpVV_QIpCNr11I6K6ry2fjFxe_6m0 (access 25.04.2021).

68 G. Hagedorn et al., Concerns of young protesters are justified, "Science", no. 364(6436)/2019, pp. 139-140, https://science.sciencemag.org/content/364/6436/139.2 .full?fbclid=IwAR3I8nMfbVBMM511G9k5x1xT9_jJLnpE5ni9toX1VImNqInul07WgVJIWFc (access 25.04.2021). 
D. Heidrich, J. Nakonieczna-Bartosiewicz, Young Activists as International...

Table 1. Nominations and Awards - Greta Thunberg

\begin{tabular}{|c|c|}
\hline DATE & NOMINATION OR AWARD \\
\hline March $8^{\text {th }}, 2019$ & Honoured as "Woman of the Year" in Sweden \\
\hline March 13th, 2019 & Nominated for Nobel Peace Prize \\
\hline March $24^{\text {th }}, 2019$ & $\begin{array}{l}\text { Nominated for and awarded the Prix Liberté. Region } \\
\text { Normandie }\end{array}$ \\
\hline March 21 ${ }^{\text {st }}, 2019$ & Awarded Golden Kamera Prize, Berlin \\
\hline April 12 $2^{\text {th }}, 2019$ & $\begin{array}{l}\text { Awarded Norwegian Fritt Ords Pris } 2019 \text { (shared with } \\
\text { Naturog Ungdom) }\end{array}$ \\
\hline June $7^{\text {th }}, 2019$ & $\begin{array}{l}\text { Fridays for Future and Greta Thunberg were awarded with } \\
\text { Amnesty International's Ambassador of Conscience award. }\end{array}$ \\
\hline December $23^{\text {rd }}, 2019$ & Person of the Year, "Time" Magazine \\
\hline October, 2019 & "GQ" magazine award for the Game Changer of the Year \\
\hline July $20^{\text {th }}, 2020$ & Awarded with first Gulbenkian Prize for Humanity \\
\hline
\end{tabular}

Source: Official posts by Greta Thunberg on Instagram.

We have also identified examples of actions of governments that can be attributed, at least partially, to the influence of meetings with Thunberg: - declarations on financing of climate policies - on February $21^{\text {st }}, 2019$, European Commission President Jean-Claude Juncker in his proposal for the EU budget pledged "In the next financial period from 2021 to 2027, every fourth euro spent within the EU budget will go towards action to mitigate climate change". His announcement was considered to be the result of Greta Thunberg's actions and the climate strike of which she is the face; ${ }^{69}$

- states' declarations on climate emergency-April $27^{\text {th }}, 2019$,Jeremy Corbyn, just a few days after meeting Greta Thunberg (the meeting took place on April 23 $3^{\text {rd }}$ 2019) launched a bid to declare a national climate emergency in the UK. ${ }^{70}$ A day later (April 28 ${ }^{\text {th }}$, 2019) Nicola Sturgeon, the First Minister of Scotland and the Leader of the Scottish National Party (SNP), declared a climate emergency at the SNP conference. The SNP leader told the delegates in Edinburgh that she was inspired after meeting young climate campaigners who had gone on strike from school. ${ }^{71}$ In May, a national

${ }^{69}$ C. Roth, op.cit.

70 T. Helm, Corbyn launches bid to declare a national climate emergency, "The Guardian", 27.04.2019, https://www.theguardian.com/environment/2019/apr/27/ corbyn-declares-national-climate-emergency (access 25.04.2021).

71 Nicola Sturgeon declares 'climate emergency' at SNP conference, "BBC News", 28.04.2019, https://www.bbc.com/news/uk-scotland-scotland-politics-48077802? fbclid= IwAR0B8kN2KTXv7q4B15wlpmZ0k5TD31y0qLw4BqofWwfiyIQCdS5o4axG8Uk (access 25.04.2021). 
climate emergency was declared by the UK Parliament. ${ }^{72}$ A similar declaration (also in May 2019) was made by the Republic of Ireland. On June $14^{\text {th }}, 2019$, a global "climate emergency" was declared by Pope Francis. He urged action indicating that young people and businesses should take a leading role. ${ }^{73} \mathrm{He}$ had met with Greta Thunberg in April $2019 ;^{74}$

- administrative actions that referred to climate policies and resulted from pressure from environmental activists (primarily mass school strikes for climate). In October 2019, the newly proposed new fossil gas terminal in Gothenburg was denied its final permit to begin construction work due to threats it might have posed to the environment. The decision was explained by the need to meet Sweden's climate targets. ${ }^{75}$

Representatives of states and international organisations have not been equivocal in their references to school climate strikes or Greta Thunberg herself. We have identified dissenting public addresses - some of them praising Thunberg's actions, some - strongly critical and sometimes even hostile.

Greta Thunberg has been strongly supported by the UN Secretary General, António Guterres, who, during the peak of protests (in March 2019), even encouraged young people to continue: "The more I see your commitment and activism, the more confident I am that we will win. Together, with your help and thanks to your efforts, we can and must beat this threat and create a cleaner, safer, greener world for everyone". ${ }^{76}$

There were, however, critical and negative opinions expressed towards Greta, her followers and their actions. The UK Prime Minister, Theresa

72 Climate change: Ireland declares climate emergency, "BBC News", 9.05.2019, https://www.bbc.com/news/world-europe-48221080?fbclid=IwAR3IhIc8RG36WBp dGZIVLEZVLJRxAvi_BrTn3SEpR6fAArkY3ErkVzckfYM (access 25.04.2021).

73 F. Harvey, J. Ambrose, Pope Francis declares 'climate emergency' and urges action, “The Guardian”, 14.06.2019, https://amp.theguardian.com/environment/2019/ jun/14/pope-francis-declares-climate-emergency-and-urges-action?_twitter_impression $=$ true \&fbclid $=$ IwAR2B0HvsfEmNTn9fsptMI6FuRg88ZavKwzI5fnxxpUdG6 SnlgziBp-HwdH4 (access 25.04.2021).

74 Pope Francis meets Greta Thunberg, "Global Catholic Climate Movement", 17.04.2019, https://catholicclimatemovement.global/pope-francis-meets-greta-thunberg/ (access 25.04.2021).

75 Fossilgasfällan page on Facebook, NEf till fossilgas $i$ Göteborgs hamn, 10.10.2019, https://www.facebook.com/watch/?v=2267774840016422 (access 25.04.2021).

76 A. Guterres, The climate strikers should inspire us all to act at the next UN summit, “The Guardian", 15.03.2019, https://www.theguardian.com/commentisfree/2019/ mar/15/climate-strikers-urgency-un-summit-world-leaders (access 25.04.2021). 
May, said that the strikes were a mere "wasting [of] lesson and teaching time" 77 , while the Prime Minister of Australia, Scott Morrison, urged "more learning and less activism condemning the school strike for climate action". ${ }^{78}$ Evidently, from among decision-makers Greta Thunberg was most strongly and adversely criticised by the former US President, Donald Trump. On September $23^{\text {rd }}, 2019$, after Thunberg's angry address given at the UN Climate Summit in New York, during which she excoriated world leaders for not doing enough to tackle the climate crisis, president Trump sarcastically mocked her on Twitter writing: "She seems like a very happy young girl looking forward to a bright and wonderful future. So nice to see!"79 He then followed on with comments on Thunberg's actions. In December 2019, after she was awarded with the Person of the Year prize by "Time" magazine, The US President, again publicly mocked her, tweeting that Greta had "anger management" issues. ${ }^{80}$ Just before the World Economic Forum Summit in Davos in 2020, Trump once again mocked her due to her age.

As mentioned before, Greta Thunberg became known to the broader public through social media. After Thunberg's actions gained publicity and aroused interest outside Sweden, Greta began to be invited to international forums. First, in October 2018 she was invited by the Extinction Rebellion to give a speech in Parliament Square in London. ${ }^{81}$ In August 2020 (2 years after the announcement of School Strike for Climate), Greta's posts on various social media profiles were being followed by millions of people. "Time" journalists have calculated that since the UN Climate Change Conference in December 2019, Thunberg's Twitter

77 J. Watts, Theresa May criticises schoolchildren protesting against looming climate disaster for wasting lesson time, "Independent", 15.02.2019, https://www.independent. co.uk/news/uk/politics/theresa-may-climate-change-school-pupils-protest-lessontime-teachers-a8781046.html (access 25.04.2021).

78 S. Bedo, PM Scott Morrison slams student protest, Greens say he is 'out of touch', "news.com.au", 27.11.2018, https://www.news.com.au/technology/environment/climate-change/why-scott-morrison-is-worse-than-tony-abbott/news-story/ac9c3a43a0097e668b5e4ab4406bcb4a (access 25.04.2021).

79 D. Trump, Post on Twitter, 24.09.2019, https://twitter.com/realdonaldtrump/ status/1176339522113679360 (access 25.04.2021).

80 "So ridiculous. Greta must work on her Anger Management problem, then go to a good old fashioned movie with a friend! Chill Greta, Chill!". D. Trump, Post on Twitter, 12.12.2019, https://twitter.com/realDonaldTrump/status/1205100602025545730 (access 25.04.2021).

${ }^{81}$ G. Thunberg, Speech at Extinction Rebellion, 31.10.2018, https://youtu.be/H8prVarP-rQ (access 25.04.2021). 
following grew by nearly $4,000 \%$ to reach 612,000 followers. ${ }^{82} \mathrm{~A}$ year later the number of Thunberg's followers on Twitter exceeded 4 million people (Facebook 3.6 million), and on Instagram 10.6 million. ${ }^{83}$

On the other hand, there are already reports indicating that Greta's activities translate into increased teenage social media presence. Ofcom (the UK governmental regulator for the communications services) in its annual own compilation from Greta Thunberg's official accounts on Twitter, Instagram and Facebook (date of estimation: August $28^{\text {th }}, 2020$ ) survey on children's media use in the UK noted that in 2019 there was an increase in the proportion of 12- to 15-year-olds who use social media to support causes and organisations by sharing and commenting on posts (from 12\% in 2018 up to $18 \%$ in the year when the survey was conducted). Ten percent of respondents from the mentioned age group signed petitions on social media. ${ }^{84}$ In the report, this increased online social consciousness among kids was named: the "Greta effect".

The number of participants in Friday demonstrations under the common slogan "Fridays for Future" (interchangeable with the "School strike for climate" ${ }^{85}$ ) systematically increased throughout 2019. In September 2018, during UN COP24 in Katowice in Poland, Greta was invited to address the participants through an official UN forum, which was a breakthrough in social mobilisation around her demands. One year later, at UN COP25 in September 2019, Greta's public appearances were accompanied by massive climate strikes worldwide. According to data provided by Fridays for Future, in March 2019, around 1.5 million people took part in these protests. In September 2019 the number of participants

82 S. Haynes, 'Now I Am Speaking to the Whole World.' How Teen Climate Activist Greta Thunberg Got Everyone to Listen, “Time”, 16.05.2019, https://time.com/collection-post/5584902/greta-thunberg-next-generation-leaders/ (access 25.04.2021).

${ }^{83}$ Own compilation from Greta Thunberg's official accounts on Twitter, Instagram and Facebook (access 28.08.2020).

84 "We have seen an increase in online social activism among children. Almost a fifth ( $18 \%$, up from $12 \%$ in a year) of $12-15$-olds use social media to express support for causes and organisations - potentially environmental, political or charitable - by sharing or commenting on posts." The Ofcom report was based on interviews with around 3,500 parents and children. Ofcom, Children And Parents: Media Use And Attitudes Report 2019, 4.02.2020, https:/www.ofcom.org.uk/aboutofcom/latest/media/media-releases/2020/rising-concern-over-children-online (access 25.04.2021).

85 As a result of the growing popularity of protest actions under the name "Fridays For Future", the name Greta Thunberg as well as the name of the movement \#FridaysForFuture and Skolstrejkförklimatet etc. have been registered as trademarks, G. Thunberg, Post on Facebook, 30.01.2020, op.cit. 
D. Heidrich, J. Nakonieczna-Bartosiewicz, Young Activists as International...

Chart 1. Comparison of frequency of browsing the terms "Greta Thunberg", "Fridays for Future", "climate strike" in Google (from August 2018 to June 2020, the whole world)

- Greta Thunberg Fridays for Future climate strike

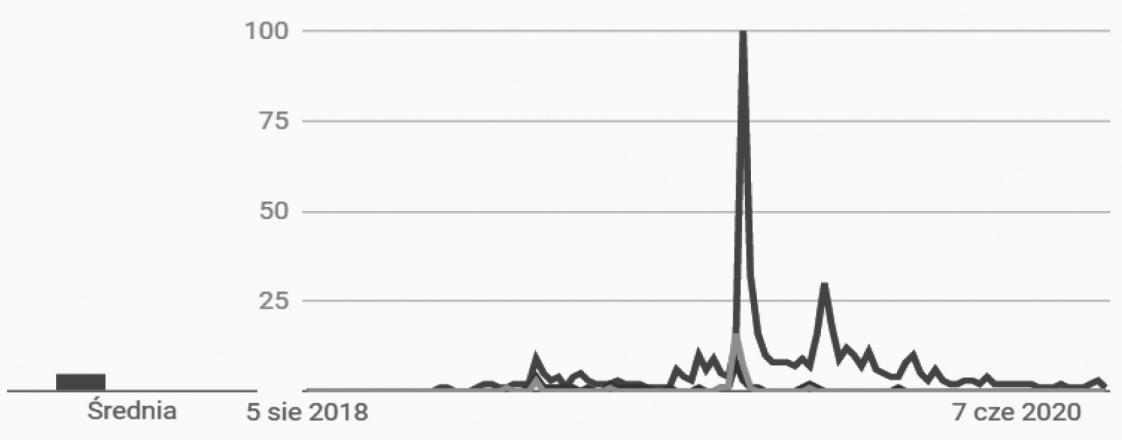

Source: Based on Google Trends, https://trends.google.pl/ (access 7.06.2020).

Chart 2. International Events Concerning Climate vs. School Climate Strike events - Timeline

\begin{tabular}{|c|c|c|c|c|c|c|c|c|c|}
\hline $\begin{array}{l}\text { School Climate } \\
\text { Strike events }\end{array}$ & 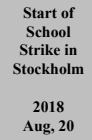 & & & $\begin{array}{c}\begin{array}{c}\text { Global Fridays } \\
\text { for Future } \\
\text { Demonstration }\end{array} \\
\quad 2019 \\
\text { March, } 15\end{array}$ & $\begin{array}{c}\text { Climate } \\
\text { Strike } \\
\\
\\
2019 \\
\text { May,24 }\end{array}$ & $\begin{array}{l}\text { Climate } \\
\text { Strike } \\
\\
2019 \\
\text { Sept, } 20\end{array}$ & $\begin{array}{l}\begin{array}{c}\text { Climate } \\
\text { Strike }\end{array} \\
\\
2019 \\
\text { Nov, } 29\end{array}$ & $\begin{array}{l}\text { Climate } \\
\text { Strike } \\
\\
2019 \\
\text { Dec, } 13\end{array}$ & \\
\hline & 2018 Aug & $2018 \mathrm{Dec}$ & 2019 Jan & 2019 March & 2019 May & 2019 Sept & $2019 \mathrm{Nov}$ & $2019 \mathrm{Dec}$ & $2020 \mathrm{Jan}$ \\
\hline $\begin{array}{c}\text { International } \\
\text { Organizations } \\
\text { Events }\end{array}$ & & $\begin{array}{c}\text { UN COP24 } \\
\text { in } \\
\text { Katowice }\end{array}$ & $\begin{array}{c}\text { WEF } \\
\text { in } \\
\text { Davos }\end{array}$ & & $\begin{array}{c}\text { Austrian } \\
\text { World } \\
\text { Summit }\end{array}$ & $\begin{array}{c}\text { UN } \\
\text { Climate } \\
\text { Action } \\
\text { Summit }\end{array}$ & & $\begin{array}{c}\text { UN COP25 } \\
\text { in } \\
\text { Madrid }\end{array}$ & $\begin{array}{c}\text { WEF } \\
\text { in } \\
\text { Davos }\end{array}$ \\
\hline
\end{tabular}

Source: Own compilation based on different sources. 


\section{Chart 3. School Strikes for Climate Events - estimated number of countries}

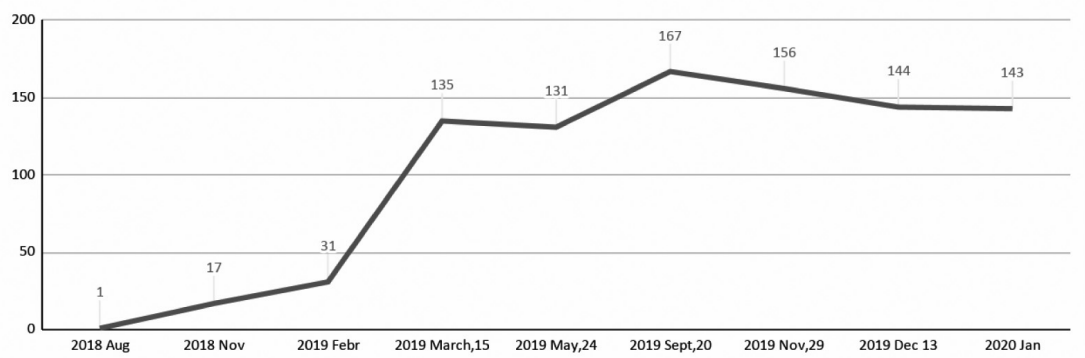

Source: Own estimation based on: https://fridaysforfuture.org/what-we-do/strikestatistics/list-of-countries/ (access 25.04.2021).

\section{Chart 4. School Strikes for Climate - estimated number of participants.}

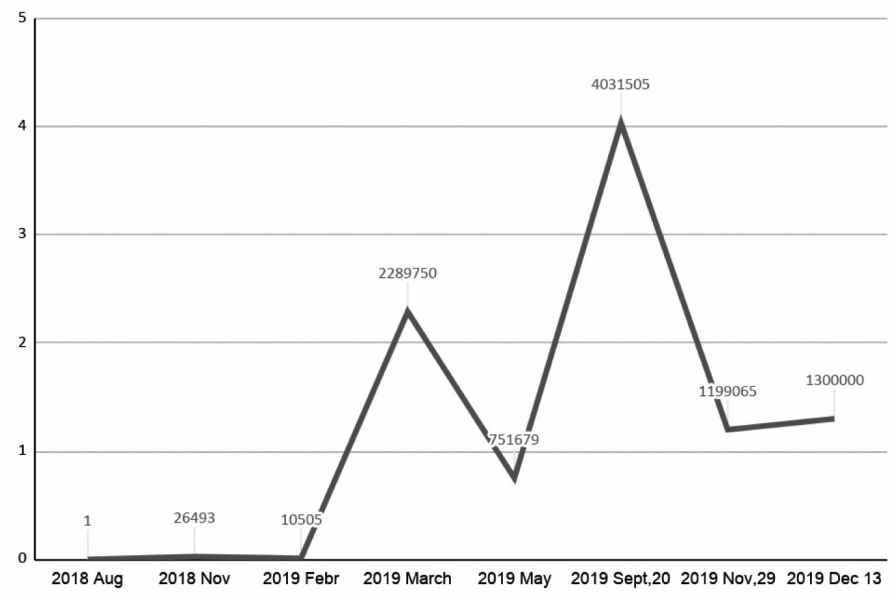

Source: Own estimation based on: https://fridaysforfuture.org/what-we-do/strikestatistics/list-of-countries/ (access 25.04.2021).

in global climate demonstrations on streets and squares exceeded 6 million people (350.org claimed that it was 7.6 million). ${ }^{86}$

The rise of interest in Greta's actions can be seen in the frequency of browsing her name and names of events associated with Greta in Google

86 M. Taylor, J. Watts, J. Bartlett, Climate crisis: 6 million people join the latest wave of global protests, “The Guardian", 27.09.2019, https://www.theguardian.com/ environment/2019/sep/27/climate-crisis-6-million-people-join-latest-wave-of-worldwide-protests (access 25.04.2021). 
presented in Chart 1. Chart 2 is a graphic summary of international governmental and other official events on climate change and accompanying strikes in the timeline. The rising interest in School strikes by the number of participants and participating countries is illustrated by Charts 3 and 4.

\section{Conclusions}

The principal purpose of this study was to fill in the research gap on young activists and their significance in the evolution and diffusion of international norms, through the example of one specific case of youth activism.

We have argued that the actions of young individuals such as Greta Thunberg can be perceived as actions characteristic of norm entrepreneurs. However, their impact on members of the international community, as well as for the international system (as a structure) can be identified only to a limited extent. The significance of young norm entrepreneurs is related to two basic characteristics of their actions: the extensive use of non-traditional organisational platforms (the Internet and social media) and the unequivocal and adamant presentation of the problems they advocate for which results from the very fact that they are children and teenagers whose voices are void of political correctness or limitations related to mature age.

The presented case study analysis shows Thunberg as a vivid actor in international normative processes for international climate regime norms. Though still young, Thunberg has been able to get the attention of and raise awareness in millions of not only other young people but also adults. She entered the already existing communication platform that transformed her individual protest in front of the Swedish parliament into a globalised, viral event attracting millions of followers. Social media (namely and specifically Instagram, later with the addition of Facebook and Twitter) created her fame and gave her the opportunity to be heard worldwide.

This paper also hypothesised that the unequivocal and adamant presentation of the problems children and teenagers advocate for are capable of attracting the attention of governmental and non-governmental actors to the issues at stake. The unprecedented scale of the social mobilisation that follows significantly influences the international debate on the particular issues (climate change in Thunberg's case) which in turn may lead to enhancing the process of the elaboration, diffusion and internalisation of international norms. Greta Thunberg specifically 
is open and very direct in her actions and speeches so as to show her disappointment and dissatisfaction with decision makers. She acts like the child character from Andersen's tale The Emperor's New Clothes, who, without any hesitation and without considering the potentially direct negative consequences, expresses the well-known but hidden truth. Thunberg is usually perceived as truly independent and altruistic. Like most young activists, she does not devote a professional career, property or any lucrative connections to this cause, as they are not in her possession. She strongly rejects suggestions about being a puppet in adults' hands, presenting evidence that she is the author of her speeches and that any income from awards and royalties are devoted to financing ecological initiatives throughout the globe.

It is important to stress that Thunberg's influence on discourse, policies and actions can be traced almost only in Europe, unless one includes the previously mentioned negative reactions from President Donald Trump or Australian Prime Minister Scott Morrison ${ }^{87}$ Even though the mobilisation of the followers of Greta's Fridays for Future have been observed in other regions around the globe, they have had little significant impact on climate change policies. Similarly, individual strikes copying the ones by Thunberg have not had much impact, and have been ridiculed and ignored. ${ }^{88}$ The reason for this may be that the EU and most of its Member States have, for a long time now, been firmly committed to basing economic and social systems on sustainable development and pro-environmental initiatives. Thus, the impatient voice of the young may be regarded by the EU as bottomup support and affirmation of the legitimacy of these efforts. In a speech alongside Thunberg, the then President of the European Commission, JeanClaude Juncker, pledged that the European Union would continue working on the European Green Deal and spend hundreds of billions of euros to combat climate change in the following decade. ${ }^{89}$ Statesmen in Ireland, ${ }^{90}$

87 Morrison responds to Greta Thunberg by warning children against 'needless' climate anxiety, “The Guardian”, 25.09.2019, https://www.theguardian.com/australianews/2019/sep/25/morrison-responds-to-greta-thunberg-speech-by-warning-children-against-needless-climate-anxiety (access 25.04.2021).

88 See for example S. Lee Myers, Ignored and Ridiculed, She Wages a Lonesome Climate Crusade, “The New York Times", 4.12.2020, https:/www.nytimes. com/2020/12/04/world/asia/ou-hongyi-china-climate.html (access 25.04.2021).

${ }^{89}$ C. Roth, Swedish student leader wins EU pledge to spend billions on climate, "Reuters", 21.02.2019, https://www.reuters.com/article/us-climatechange-teen-activistidUSKCN1QA1RF (access 25.04.2021).

${ }_{90}$ Climate change: Ireland declares climate emergency..., op.cit.; C. Martin, TD Twitter, 9.05.2019, https://twitter.com/cathmartingreen/status/1126548324440473600?s $=20$ (access 25.04.2021). 
Scotland, ${ }^{91}$ the UK, ${ }^{92}$ and the Vatican, ${ }^{93}$ mentioning Thunberg's actions, have all declared climate emergencies. In October 2019, a proposed new fossil gas terminal in Göteborg, Sweden was denied its final construction permit and will not be built because of the climate crisis and it might, at least to some extent, be related to Thunberg's popularity in Swedish society and politics. ${ }^{94}$ It is, however, impossible to prove that Thunberg's actions have been a decisive factor in policies and action modifications. We rather conclude that she has strengthened the validity of the already existing discourse and argumentation.

What remains unclear at this stage of our research on young activists and their role in international norm development and diffusion is whether the conclusions on Greta might be generalised to youth activism as a wider phenomenon. Children are traditionally perceived as insignificant to normative change in IR and as individuals with a limited agency who rather need protection and education and are seldom admired for their initiatives in the public domain. However, as the case of Greta Thunberg proves, the actions of children and teenagers allow them to access and influence a breadth of audience that is unprecedented and these actions also have the potential to enhance normative processes.

\section{Acknowledgments}

We are grateful to Professor Jakub Zajączkowski and Professor Roberto Rabel for their insightful comments and suggestions which significantly helped us to improve the various drafts of the manuscript.

${ }^{91}$ Nicola Sturgeon declares 'climate emergency' at SNP conference..., op.cit.

92 Corbyn said the climate protests were "a massive and necessary wake-up call" that demanded "rapid and dramatic action, which only concerted government action and a green industrial revolution can deliver." T. Helm, op.cit.

93 Pope Francis declaring a 'climate emergency', pointing out, "Future generations stand to inherit a greatly spoiled world. Our children and grandchildren should not have to pay the cost of our generation's irresponsibility (...) Indeed, as is becoming increasingly clear, young people are calling for a change.” F. Harvey, J. Ambrose, op.cit.

94 Fossilgasfällan, op.cit. 


\section{References}

Anderson K., Making Sense of State Socialization, "Review of International Studies", no. 27/2001, DOI: https://doi.org/10.1017/ S0260210501004156.

Axelrode R., An Evolutionary Approach to Norms, "American Political Science Review", no. 80(4)/1986, DOI: https://doi.org/10.1017/S0003 055400185016.

Bakker K., Baptism of fire?’ The first climate case before the UN Committee on the Rights of the Child, "QIL, Zoom-in", no. 77/2021.

Bedo S., PM Scott Morrison slams student protest, Greens say he is 'out of touch', "news.com.au", 27.11.2018, https://www.news.com.au/technology/ environment/climate-change/why-scott-morrison-is-worse-thantony-abbott/news-story/ac9c3a43a0097e668b5e4ab4406bcb4a (access 25.04.2021).

Björkdahl A., From Idea to Norm-Promoting Conflict Prevention, "Lund Political Studies. Department of Political Science, Lund University", no. $125 / 2002$.

Brut.com, 16-year-old Greta Thunberg In A Brut Interview, "Brut.com", 19.02.2020, https://www.facebook.com/watch/?v=2612830962066751 (access 25.04.2021).

Checkel J.T., Norms, Institutions and National Identity in Contemporary Europe, "International Studies Quarterly", no. 43(1)/1999, DOI: https://doi.org/10.1111/0020-8833.00112.

Climate change: Ireland declares climate emergency, "BBC News", 9.05.2019, https:/www.bbc.com/news/world-europe-48221080? fbc lid = I w A R 3 I h I c 8 R G 36 W B pd GZ1VLEZ V L J R x A vi BrTn3SEpR6fAArkY3ErkVzckfYM (access 25.04.2021).

Climate Media Coalition: http://climatemediacoalition.org/ (access 25.04. 2021).

Climate Strike 2015: Students Skip School demanding Climate Actions. Climate Strike, 1.03.2016, https://www.youtube.com/watch?v=0GjdVgGfcb8 (access 25.04.2021).

Corner A., et al., How do Young People Engage with Climate Change? The Role of Knowledge, Values, Message Framing, and Trusted Communicators, "WIREs Climate Change", no. 6/2015, DOI: https://doi.org/10.1002/wcc.353.

Cortell A.P., Davies J.W., Understanding the Domestic Impact of International Norms: A Research Agenda, "International Studies Review", no. 2(1)/2000, DOI: https://doi.org/10.1111/1521-9488.00184.

EUIPN, https://www.tmdn.org/tmview/get-detail?st13=EM50000001817 1383\&lang $=$ en $\#($ access 25.04.2021). 
European Court of Human Rights, Communicated Case: Duarte Agostinho et Autres c. Portugal et 32 Autres États, 39371/20, http://hudoc.echr. coe.int/eng? $\mathrm{i}=001-206535$ (access 25.04.2021).

Finnemore M., Sikkink K., International Norm Dynamics and Political Change, "International Organization", no. 52(4) 1998, DOI: https:// doi.org/10.1162/002081898550789.

Finnemore M., National Interests in International Society, Cornell University Press, Ithaca 1996, DOI: https://doi.org/10.7591/9781501707384.

Fisher D.R., Teen girls are leading the climate strikes and helping change the face of environmentalism, "The Washington Post", 24.09.2019, https://www. washingtonpost.com/science/2019/09/24/teen-girls-are-leadingclimate-strikes-helping-change-face-environmentalism/ (access 25.04.2021).

Fisher D., et al., How Do Organisations Matter? Mobilisation and Support for Participants at Five Globalization Protests, "Social Problems", no. 52(1)/2005, DOI: https://doi.org/10.1525/sp.2005.52.1.102.

Fisher S.R., Life Trajectories of Youth Committing to Climate Activism, "Environmental Education Research", no. 22(2)/2015, DOI: https:// doi.org/10.1080/13504622.2015.1007337.

Florini A., The Evolution of International Norms, "International Studies Quarterly", no. 40(3)/1996, DOI: https://doi.org/10.2307/2600716.

Forbrig J., Introduction: democratic politics, legitimacy and youth participation, in: Revisiting Youth Political Participation: Challenges for Research and democratic practice in Europe, ed. J. Forbrig, Council of Europe Publishing, Strasbourg 2005.

Fossilgasfällan, NEf till fossilgas $i$ Göteborgs hamn, 10.10.2019, https:// www.facebook.com/Fossilgasfallan/videos/2267774840016422 (access 25.04.2021).

GLAN, Press Release: Unprecedented climate case clears major hurdle as European court recognises "importance and urgency", 30.11.2020, https:// youth4climatejustice.org/wp-content/uploads/2020/11/GLANCLIMATE-CASE-PRESS-RELEASE-embargoed-until-00.0130.11.20-1.pdf (access 25.04.2021).

Greta Thunberg and children's group hit back at attempt to throw out climate case, “The Guardian”, 5.05.2020, https://www.theguardian.com/ environment/2020/may/05/greta-thunberg-and-childrens-group-hitback-at-attempt-to-throw-out-climate-case (access 25.04.2021).

Guterres A., The climate strikers should inspire us all to act at the next UN summit, "The Guardian", 15.03.2019, https://www.theguardian.com/ commentisfree/2019/mar/15/climate-strikers-urgency-un-summitworld-leaders (access 25.04.2021). 
Hagedorn G.P., et al., Concerns of young protesters are justified, "Science", no. 364(6436), 12.04.2019, https://science.sciencemag.org/content/ 364/6436/139.2.full?fbclid = IwAR3I8nMfbVBMM511G9k5x1xT9 jJLnpE5ni9toX1VImNqInul07WgVJIWFc (access 25.04.2021).

Harvey F., Ambrose J., Pope Francis declares 'climate emergency' and urges action, "The Guardian", 14.06.2019, https://amp.theguardian.com/ environment/2019/jun/14/pope-francis-declares-climate-emergencyand-urges-action?_twitter_impression $=$ true $\& f b c l i d=I w A R 2 B 0 H v$ sfEmNTn9fsptMI6FuRg88ZavKwzI5fnxxpUdG6SnlgziBp-HwdH4 (access 25.04.2021).

Haynes S., 'Now I Am Speaking to the Whole World.' How Teen Climate Activist Greta Thunberg Got Everyone to Listen, “Time”, 16.05.2019, https://time. com/collection-post/5584902/greta-thunberg-next-generation-leaders/ (access 25.04.2021).

Helm T., Corbyn launches bid to declare a national climate emergency, "The Guardian", 27.04.2019, https://www.theguardian.com/ environment/2019/apr/27/corbyn-declares-national-climate-emergency (access 25.04.2021).

Holmberg A., Alvinius A., Children's Protest in Relation to the Climate Emergency: A Qualitative Study on a New Form of Resistance Promoting Political and Social Change, "Childhood", no. 27(1)/2020, DOI: https:// doi.org/10.1177/0907568219879970.

Jacobsen J.K., Much Ado About Ideas: The Cognitive Factor in Economic Policy, "World Politics", no. 47(2)/1995, DOI: https://doi.org/10.1017/ S0043887100016117.

Kann D., Greta Thunberg and 15 other children filed a complaint against five countries over the climate crisis, "CNN", 23.09.2019, https://edition.cnn. com/2019/09/23/world/united-nations-greta-thunberg-children-climatechange-human-rights-complaint/index.html. (access 25.04.2021).

Keck M., Sikkink K., Activists beyond Borders: Advocacy Networks in International Politics, Cornell University Press, Ithaca, NY 1999.

Krasner S.D., International Regimes, Cornell University Press, Ithaca, NY 1983.

Krasner S.D., Structural Causes and Regime Consequences: Regimes as Intervening Variables, "International Organization", no. 36(2)/1982, DOI: https://doi.org/10.1017/S0020818300018920.

Lee M.S., Ignored and Ridiculed, She Wages a Lonesome Climate Crusade, "The New York Times", 4.12.2020, https://www.nytimes.com/2020/12/04/ world/asia/ou-hongyi-china-climate.html (access 25.04.2021).

Lessig L., The Regulation of Social Meaning, "University of Chicago Law Review", no. 62(3)/1995, DOI: https://doi.org/10.2307/1600054. 
Madokoro D., International commissions as norm entrepreneurs: Creating the normative idea of the responsibility to protect, "Review of International Studies", no. 45(1)/2019, DOI: https://doi.org/10.1017/ S0260210518000219.

Martin C., TD Twitter, 9.05.2019, https://twitter.com/cathmartingreen/ status $/ 1126548324440473600 ? \mathrm{~s}=20$ (access 25.04 .2021 ).

Merkel meets Thunberg and other climate activists, "DW News", 20.08.2020, https://www.dw.com/en/merkel-meets-thunberg-and-other-climateactivists/av-54641827 (access 25.04.2021).

Moravcsik A., A New Statecraft? Supranational Entrepreneurs and International Cooperation, "International Organization", no. 53(2)/1999, DOI: https://doi.org/10.1162/002081899550887.

Morrison responds to Greta Thunberg by warning children against 'needless' climate anxiety, "The Guardian", 25.09.2019, https://www.theguardian. com/australia-news/2019/sep/25/morrison-responds-to-gretathunberg-speech-by-warning-children-against-needless-climateanxiety (access 25.04.2021).

Murthy D., Introduction to Social Media, Activism, and Organizations, "Social Media + Society", no. 4(1)/2018, DOI: https://doi.org/10.1177/ 2056305117750716.

Nadelmann E.A., Global Prohibition Regimes: The Evolution of Norms in International Society, "International Organization", no. 44(4)/1990, DOI: https://doi.org/10.1017/S0020818300035384.

Nicola Sturgeon declares 'climate emergency' at SNP conference, "BBC News", 28.04.2019, https://www.bbc.com/news/uk-scotland-scotland-politics48077802?fbclid=IwAR0B8kN2KTXv7q4B15wlpmZ0k5TD31y0qLw 4BqofWwfiyIQCdS5o4axG8Uk (access 25.04.2021).

Ofcom, Children And Parents: Media Use And Attitudes Report 2019, 4.02.2020, https://www.ofcom.org.uk/about-ofcom/latest/media/mediareleases/2020/rising-concern-over-children-online (access 25.04.2021).

OHCHR, The case is still pending before the committee. Table of Pending Cases before the Committee on the Rights of the Child, https://www.ohchr.org/ Documents/HRBodies/CRC/TablePendingCases.pdf (access 25.04.2021). Open Letter of scholars, School climate strike children's brave stand has our support, "The Guardian", 13.02.2019, https://www.theguardian.com/ environment $/ 2019 / \mathrm{feb} / 13 /$ school-climate-strike-childrens-bravestand-has-our-support?fbclid =IwAR3n8aFnEYECFk7w4IeV7UEwV d_oehNpVV_QIpCNr1lI6K6ry2fjFxe_6m0 (access 25.04.2021).

Paris Agreement to the United Nations Framework Convention on Climate Change, 12.12.2015, https://unfccc.int/files/meetings/paris_nov_2015/ application/pdf/paris_agreement_english_.pdf (access 25.04.202立). 
Pollack M.A., Delegation, Agency, and Agenda Setting in the European Community, "International Organization", no. 51(1)/1997, DOI: https:// doi.org/10.1162/002081897550311.

Pope Francis meets Greta Thunberg, "Global Catholic Climate Movement", 17.04.2019, https://catholicclimatemovement.global/pope-francismeets-greta-thunberg/ (access 25.04.2021).

Roth C., Swedish student leader wins EU pledge to spend billions on climate, "Reuters", 21 February 2019, https://www.reuters.com/article/usclimatechange-teen-activist-idUSKCN1QA1RF (access 25.04.2021).

Rushton S., The UN Secretary-General and Norm Entrepreneurship: Boutros Boutros-Ghali and Democracy Promotion, "Global Governance", no. 14(1)/2008, DOI: https://doi.org/10.1163/19426720-01401007.

Severn Cullis-Suzuki Speech at the Rio Summit 1992, https://youtu.be/oJJ GuIZVfLM?list $=$ PLfAjqE6VVDpUMolbS930 mnv92yMuQAolw (access 25.04.2021).

Stoeckl K., The Russian Orthodox Church as moral norm entrepreneur, "Religion, State \& Society", no. 44(2)/2016, DOI: https://doi.org/10.10 80/09637494.2016.1194010.

Subotić J., Hijacked Fustice. Dealing with the Past in the Balkans, Cornell University Press, Ithaca-London 2009.

Suzuki S., Tell the World, Doubleday Canada, 1993.

Taylor M., Watts J., Bartlett J., Climate crisis: 6 million people join the latest wave of global protests, "The Guardian", 27.09.2019, https://www. theguardian.com/environment/2019/sep/27/climate-crisis-6-millionpeople-join-latest-wave-of-worldwide-protests (access 25.04.2021).

Thew H., et al., Youth participation and agency in the United Nations Framework Convention on Climate Change, "Int Environ Agreements", no. 18/2018, DOI: https://doi.org/10.1007/s10784-018-9392-2.

Thew H., Middlemiss L., Paavola J., "Youth is not a political position": Exploring justice claims-making in the UN Climate Change Negotiations, "Global Environmental Change", no. 61/2020, DOI: https://doi. org/10.1016/j.gloenvcha.2020.102036.

Thunberg G., "You did not act in time": Greta Thunberg's full speech to $M P s$, “The Guardian", 23.04.2019, https://amp.theguardian.com/ environment/2019/apr/23/greta-thunberg-full-speech-to-mps-youdid-not-act-in-time? twitter_impression $=$ true \&fbclid $=$ IwAR1y7 qFbZzwtyFEuiM $\overline{C H} 4$ qL $\overline{d j}$ Klh 0 W SW 81 Rlffu N 5 z L Hxqez JqvluiVp3w (access 25.04.2021).

Thunberg G., Address at the COP24 plenary session, 12.12.2018, https:// www.youtube.com/watch?v $=$ Z1znxp8b65E (access 25.04.2021).

Thunberg G., Neubauer L., Valenzuela A., Why We Strike Again, Article- 
Call, "Project Syndicate", 29.11.2019, https://www.project-syndicate. $\mathrm{org} /$ commentary/climate-strikes-un-conference-madrid-by-gretathunberg-et-al-2019-11 ?fbclid =IwAR3XjvypiCJXAkAhTTpWEBx2a YEBnn4Y8 83NGqDzJhpgeOXCFC3Jtb2w3o (access 25.04.2021).

Thunberg G., $\bar{N}$ o One Is Too Small to Make a Difference, Penguin Books Ltd., London 2019.

Thunberg G., Post on Facebook, 11.02.2019, https://www.facebook.com/ gretathunbergsweden/photos/a.733630957004727/773673599667129/?t ype $=3 \&$ theater $($ access 25.04.2021).

Thunberg G., Post on Facebook, 17.03.2019, https://www.facebook.com /732846497083173/posts/793441724356983 (access 25.04.2021).

Thunberg G., Post on Facebook, 30.01.2020, https://www.facebook.com/ gretathunbergsweden/photos/a.733630957004727/1047447982289688/ ?type $=3 \&$ theater (access 25.04.2021).

Thunberg G., School strike for climate - save the world by changing the rules, TEDx Stockholm, November 2018, https://www.ted.com/talks/greta thunberg_the_disarming_case_to_act_right_now_on_climate_change (access 25.04.2021).

Thunberg G., Speech "Our House is on Fire", World Economic Forum (WEF) in Davos, January 2019, https://youtu.be/M7dVF9xylaw (access 25.04.2021).

Thunberg G., Speech at Extinction Rebellion, 31.10. 2018, https://youtu.be / H8prVarP-rQ (access 25.04.2021).

Thunberg G., Speech at the Brilliant Minds conference in Stockholm, 13.06.2019, https://www.facebook.com/watch/?v = 1454977894643083 (access 25.04.2021).

Thunberg G., Speech at the EU Parliament in Strasbourg, 16.04.2019, https:// youtu.be/cJAcu QEVxTY (access 25.04.2021).

Thunberg G., Speech at the National Assembly in Paris, 23.07.2019, https:// youtu.be/ESDpzwWrmGg (access 25.04.2021).

Thunberg G., Speech At The UN Climate Action Summit, 23.09.2019, https:// www.youtube.com/watch?v $=$ u9KxE4Kv9A8 (access 25.04.2021).

Thunberg G., Speech to the US Congress, Washington D.C., 18.09.2019, "Independent", Transcript, 20.09.2019, https://www.independent. co.uk/voices/greta-thunberg-congress-speech-climate-change-crisisdream-a9112151.html (access 25.04.2021).

Thunberg G., Speech to UN secretary-general António Guterres at UN Climate Change COP24 Conference, 3.12.2018, https://youtu.be/Hq489387cg4 (access 25.04.2021).

Thunberg G., et al., Think we should be at school? Today's climate strike is the biggest lesson of all, "The Guardian", 15.03.2019, https://www. 
theguardian.com/commentisfree/2019/mar/15/school-climate-strikegreta-thunberg (access 25.04.2021).

Trump D., Post on Twitter, 12.12.2019, https://twitter.com/realDonald Trump/status/1205100602025545730 (access 25.04.2021).

Trump D., Post on Twitter, 24.09.2019, https://twitter.com/ realdonaldtrump/status/1176339522113679360 (access 25.04.2021).

Watts J., Theresa May criticizes schoolchildren protesting against looming climate disaster forwasting lesson time, "Independent", 15.02.2019, https:// www.independent.co.uk/news/uk/politics/theresa-may-climatechange-school-pupils-protest-lesson-time-teachers-a8781046. $\mathrm{html}$ (access 25.04.2021).

Wendt A., The Social Theory of international politics, Cambridge University Press, Cambridge 1999, DOI: https://doi.org/10.1017/CBO978 0511612183.

Yee A.S., The Causal effect of Ideas on Policies, "International Organization", no. 50(1)/1996. 